\title{
A Diagnostic Study of Interaction of Cumulus Updrafts and Downdrafts with Large-Scale Motions in GATE
}

\author{
By Tsuyoshi Nitta \\ Geophysical Institute, Tokyo University, Tokyo, Japan \\ (Manuscript received 26 April 1978, in revised form 20 June 1978)
}

\begin{abstract}
A diagnostic method including cumulus updrafts and downdrafts is applied to GATE A/B-scale upper-air observations for Phase III to study the interaction of the cumulus convection with large-scale motions. Average results for Phase III show that the mass fluxes for deep and shallow clouds are larger than those for clouds with tops in the middle troposphere and downward mass fiuxes equivalent to $40 \% \sim 50 \%$ of updrafts convective mass fluxes are accomplished by cumulus downdrafts.

Correlation coefficients between deep, middle and shallow cloud mass fluxes and the large-scale vertical velocity are computed to examine the response of cumulus clouds to the large-scale forcing. The results show that deep clouds are highly correlated with the largescale vertical velocity at all levels, middle clouds have little correlations and shallow clouds are correlated only with the vertical velocity near cloud base. Maximum activity of deep clouds occurs nearly at the same time as maximum large-scale upward motion at higher levels but about $6 \mathrm{~h}$ after maximum low-level convergence. Strongest downdraft mass fiuxes occur corresponding to maximum deep cloud activity. Shallow cloud mass fluxes have negative correlations with the low-level convergence indicating that shallow cloud activity is weak when the low-level convergence is large.

A compositing method is used to clarify relationships between the cumulus convection and the African wave disturbance observed during GATE. Maximum deep cloud mass fiux is found in the region near the wave trough where the large-scale vertical velocity has a peak. This is also the region where largest downdraft cloud mass fluxes exist. Shallow cloud activity is weak near the wave trough but strong near the wave ridge. Weak subsidence with amplitude of a few $\mathrm{mb} \mathrm{h}^{-1}$ is present nearly everywhere in the environment of the clouds in the wave disturbance, but slightly larger subsidence occurs in the regions where shallow cloud mass fluxes dominate.
\end{abstract}

\section{Introduction}

In recent years, extensive diagnostic studies of the interaction between large-scale motion systems and cumulus convection have been performed in parallel with theoretical studies (Ooyama, 1971; Betts, 1973; Arakawa and Schubert, 1974). Yanai et al. (1973) proposed a method to determine bulk properties of a cumulus ensemble from large-scale heat and moisture budgets. Ogura and Cho (1973) and Nitta (1975) refined the method by using spectral representation of the cumulus ensemble introduced by Arakawa and Schubert (1974). Johnson (1976) and Nitta (1977) further included cumulus downdrafts into their diagnostic cloud models in somewhat different manners and obtained similar conclusions that cumulus downdrafts contribute significantly to large-scale heat and moisture budgets through cooling and moistening effects.

Cho and Ogura (1974) applied their diagnostic method to Reed-Recker's composite easterly waves and showed that shallow clouds are present everywhere in the wave disturbances although deep cloud activity is limited mainly to the wave trough region. Yanai et al. (1976) analyzed a relationship between large-scale processes and cumulus clouds using a data set in the Marshall Islands area for a 100-day period and found that shallow clouds persist nearly all the time but deep clouds are highly correlated with the largescale vertical velocity at higher levels.

The GARP Atlantic Tropical Experiment (GATE) has given us a good opportunity to 
increase an understanding of the interaction between large-scale motions and the cumulus convection using an excellent data set. Reed et al. (1977) obtained the structure of African wave disturbances observed during GATE Phase III by a compositing method and found that greatest convective activity and largest precipitation amount occur ahead of the wave trough where maximum low-level convergence exists. Nitta (1977), hereafter referred to as $\mathrm{N}$, analyzed response of cumulus updrafts and downdrafts for different stages of cloud clusters using GATE A/B-scale observations during two priority periods in Phase III and showed that the very deep clouds are greatly enhanced and a strong downdraft whose amplitude is $\sim 40-50 \%$ of the updraft occurs during an active stage of cloud clusters.

The present study is a continuation of the previous study of $N$ and has a purpose to clarify relationships between cumulus updrafts, downdrafts and the large-scale forcing by using upperair observations over GATE A/B-scale area for full periods of Phase III. Recently Johnson (1978) applied a diagnostic method including both cumulus updrafts and downdrafts to budget results of African wave disturbances composited by Reed et al. (1977) and obtained the meridionally varying response of cumulus clouds to large-scale forcing. The present work differs from his study in several respects:

(1) Cloud mass fluxes for updrafts and downdrafts are determined by using a different method as discussed in $N$.

(2) Upper-air observations over GATE A/Bscale area which are suitable for detailed budget computations are used.

(3) Computations for cumulus mass fluxes are carried out for each observation time. Original time series of computational results as well as wave compositing are used to analyze relationships between large-scale motions and the cumulus convection.

\section{Data and method of analysis}

Upper-air observation taken during Phase III (31 August-18 September 1974) in the GATE A/B-scale area are used in this analysis. Fig. 1 shows A/B- and B-scale ship distributions during Phase III. The A/B-scale network consists of seven U.S.S.R. ship stations. The basic parameters (temperature, relative humidity, wind velocity and wind direction) are interpolated at constant pressure levels with a vertical resolution of $25 \mathrm{mb}$

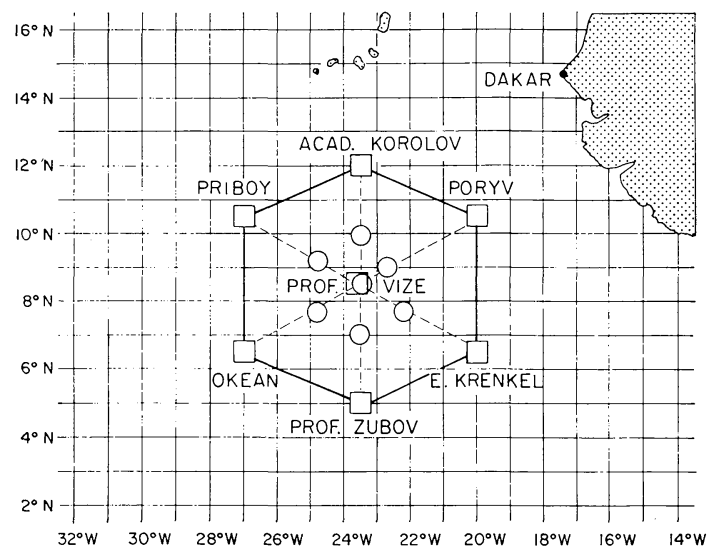

Fig. 1 Upper-air observation networks for A/Band B-scale during GATE Phase III. Squares denote stations used in this study. The hexagonal area enclosed by solid lines is the GATE A/B-scale area used for budget computations.

at regular 6 hourly observation times. Detailed procedures of data processing are described in $N$.

A large-scale apparent heat source $Q_{1}$ and an apparent moisture sink $Q_{2}$ are computed by

$$
\begin{aligned}
Q_{1} & \equiv \frac{c_{p}}{\left(p_{0} / p\right)^{\kappa}}\left(\frac{\partial \bar{\theta}}{\partial t}+\overline{\boldsymbol{V} \cdot \bar{\nabla}} \bar{\theta}+\bar{\omega} \frac{\partial \bar{\theta}}{\partial p}\right), \\
Q_{2} & \equiv-L\left(\frac{\partial \bar{q}}{\partial t}+\overline{V \cdot \nabla} \bar{q}+\bar{\omega} \frac{\partial \bar{q}}{\partial p}\right),
\end{aligned}
$$

where over-bars denote area-averages over the A/B-scale area, $\theta$ the potential temperature, $q$ the mixing ratio of water vapor, $p_{o}=1,000 \mathrm{mb}$, $c_{p}$ the specific heat of air under constant pressure, $\kappa=R / c_{p}$ and $L$ the latent heat of condensation. The method for budget computations is the same as that used in $N$ except for the following point. Ooyama and Esbensen (1977) reported that there are large temperature differences between the RKZ sondes used by the U.S.S.R. and the VIZ sondes used by the U.S., Canada, France, and Germany probably due to the bias of the height measurements for the U.S.S.R. sondes and that those temperature difference are found even among the U.S.S.R. ships. According to their analysis the largest discrepancies involve the VIZE and ZUBOV soundings. Therefore in our budget computations $\theta$ and $q$ at these two stations are not used and these parameters at each level using the data from five remaining ships are fitted linearly in space by a least square method.

A diagnostic cloud model developed by $N$ is applied to the large-scale budget results. This 
model includes both convective updrafts and downdrafts. Following $N$, the equations of the large-scale heat and moisture budgets are

$$
\begin{aligned}
& Q_{1}-Q_{R}=\delta_{u}\left(\hat{s}_{u}-\bar{s}\right)-L \delta_{u} \hat{l}_{u}-M_{u} \frac{\partial \bar{s}}{\partial p} \\
& \quad+\delta_{d}\left(\hat{s}_{d}-\bar{s}\right)-M_{d} \frac{\partial \bar{s}}{\partial p}, \\
& -Q_{2}=L \delta_{u}\left(\hat{q}_{u}-\bar{q}+\hat{l}_{u}\right)-L M_{u} \frac{\partial \bar{q}}{\partial p} \\
& -L \delta_{d}\left(\hat{q}_{d}-\bar{q}\right)-L M_{d} \frac{\partial \bar{q}}{\partial p},
\end{aligned}
$$

where $Q_{R}$ is the radiational heating, $M$ the total cloud mass flux, $\delta$ the rate of mass detrainment per unit pressure interval, $\hat{s}, \hat{q}$ and $\hat{l}$ are the dry static energy, mixing ratios of water vapor and liquid water of clouds at the detrainment level and ()$_{u}$ and ()$_{d}$ denote the properties of updrafts and downdrafts, respectively. The cloud models and assumptions for updrafts and downdrafts are given in $N$, and the updraft cloud base mass fluxes, $M_{B}\left(p_{D}\right)$, as a function of the cloud detrainment level $p_{D}$, and the downdraft cloud mass fluxes, $M_{d}(p)$, are determined by solving (3) and (4). Computations of large-scale budgets and cloud mass fluxes are carried out for each 6 hourly observation time.

\section{Average large-scale heat and moisture budgets and cloud mass fluxes}

Fig. 2 shows the average profiles of the horizontal divergence and the relative vorticity. The low-level convergence is one of characteristic features in GATE which differ from those observed over the other tropical oceanic areas. A large divergence which may correspond to outflows from deep clouds occurs in the upper troposphere around $250 \mathrm{mb}$. Weak divergence

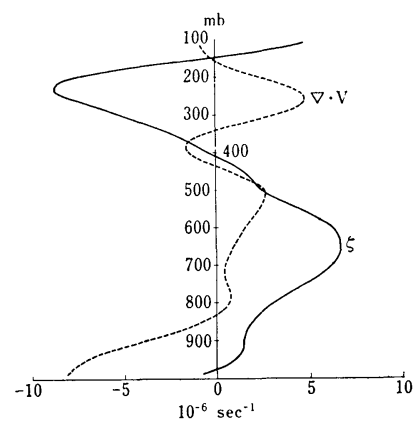

Fig. 2 Average vertical profiles of the relative vorticity and the horizontal divergence for Phase III.

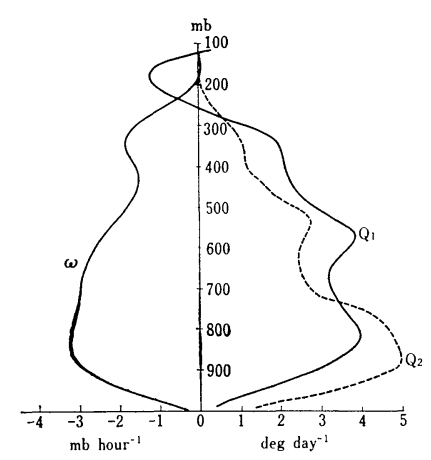

Fig. 3 Average vertical profiles of the vertical $p$-velocity, the apparent heat source and the apparent moisture sink for Phase III.

and convergence are found in the middle layer. There is a deep layer of cyclonic vorticity with a peak near $650 \mathrm{mb}$, and a layer of anticyclonic vorticity in the upper troposphere.

The average distributions of the vertical velocity, and the large-scale apparent heat source and moisture sink are presented in Fig. 3. The vertical velocity has a maximum at about $800 \mathrm{mb}$ due to the strong low-level convergence. An apparent heat source and a moisture sink are predominant throughout the troposphere except above $250 \mathrm{mb}$ where about $1 \mathrm{deg}^{\mathrm{day}}{ }^{-1}$ cooling takes place. The climatological values of $Q_{R}$ (not shown) obtained by Dopplick (1970) is used in this study. The cooling above $250 \mathrm{mb}$ may be due to radiational effects of dense cirrus clouds or due to overshooting effects by deep cumulus clouds, or both, as suggested by Frank (1977). The use of the proper radiational profiles and the improvement of the diagnostic cloud model including overshooting effects will be desired in future.

Fig. 4 shows the average profiles of cloud base mass fluxes for updrafts, total cloud mass fluxes due to updrafts and downdrafts, net cloud mass fluxes and mass fluxes in the environment of the clouds. On the average a bimodal distribution of the cloud base mass fluxes is obtained. However this does not mean that both deep and shallow clouds are always co-existing. Unimodal distributions with deep or shallow clouds dominating are frequently observed as will be shown in the next section. There exist strong convective downdraft mass fluxes equivalent to about $40 \% \sim 50 \%$ of updraft mass fluxes in the middle and lower troposphere. The net upward mass flux inside clouds is slightly larger than the area- 

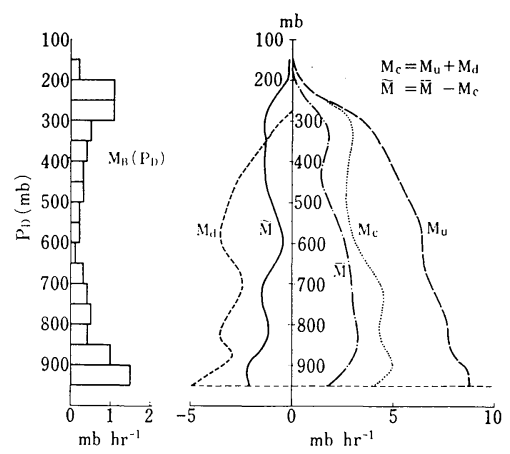

Fig. 4 Average cloud base mass flux for updrafts as a function of the detrainment level $M_{B}\left(p_{D}\right)$, total updraft mass flux $M_{\imath,}$, total downdraft mass flux $M_{d}$, net cloud mass flux $M_{c}$, area-averaged mass flux $\bar{M}$ and environmental mass flux between clouds $\widehat{M}$ for Phase III.

averaged mass flux suggesting the existence of weak subsidence between clouds.

As discussed by Johnson (1976) and Nitta (1977) the cloud downdraft plays an important role in the large-scale heat and moisture budgets and the neglect of the downdraft in the diagnostic cloud model leads to the overestimation of the shallow cloud mass flux. Downdrafts associated with a squall-line have been frequently observed during GATE. Recently, Houze (1977) and Zipser (1977) have made an extensive analysis on tropical squall-line systems over the GATE area. They observed the two different kinds of downdrafts to the rear of the squall-lines, i.e., one is the saturated convective-scale downdraft and the other is the unsaturated mesoscale downdraft below the trailing anvil cloud. Since the downdraft adopted in this study represents the average downdraft over the analyzed area, this diagnostic method is applicable to the situation in which different types of downdrafts exist as long as the fractional rate of total area for downdrafts is much smaller than unity. Further analysis is needed to evaluate the fractional rate of area for downdrafts correctly to check this assumption.

\section{Response of deep and shallow clouds to large- scale forcing}

Large-scale motion systems vary in time during Phase III and cumulus cloud activity is coupled with these variations. In this section we examine the time variations of the large scale motions and cloud activity to determine how cumulus clouds respond to the large-scale forcing. Fig. 5 shows the vertical-time section of the relative vorticity. The relative vorticity in the middle and lower troposphere varies with a period of about 3-4 days with a maximum amplitude near 700 mb. These variations are mostly due to the passage of the African wave disturbances analyzed by Reed et al. (1977). In the upper troposphere the anticyclonic circulation predominates but its amplitude also exhibit time variations with a period of a few days. The vertical-time distribution of the vertical velocity is presented in Fig. 6. In general upward motions dominate the whole troposphere but their amplitudes vary according to the passage of the wave disturbances. Strong rising motions occur in the vicinity of the wave troughs.

Fig. 7 shows the distribution of the cloud base mass flux as a function of the detrainment pressure level. As seen in the time-average profiles in the previous section, the contributions of deep and shallow cloud mass fluxes to the total cloud mass fluxes are much larger than the contribution due to clouds with tops in the middle tropo-

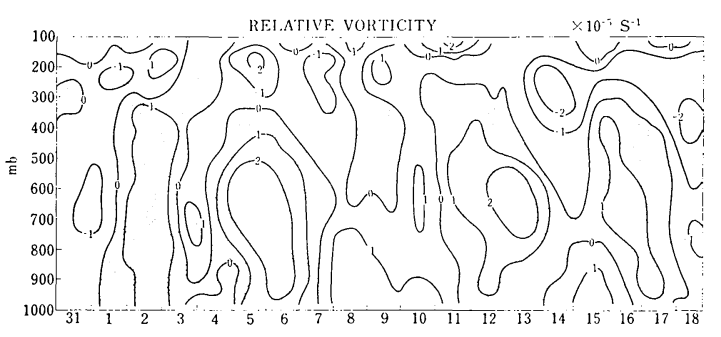

Fig. 5 Vertical-time section of the relative vorticity. Regions of the positive relative vorticity are shaded.

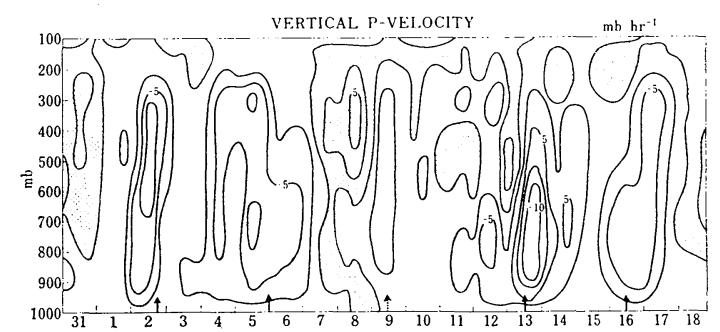

Fig. 6 Vertical-time section of the area-averaged vertical $p$-velocity. Regions of the downward motion are shaded. Arrows denote the time points when the wave troughs pass through the analyzed area. 


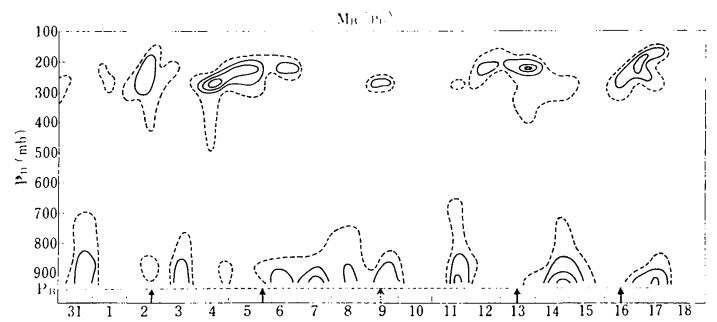

Fig. 7 Time section of the cloud base mass flux as a function of the detrainment level. Solid lines are isolines with intervals of $2 \mathrm{mb} \mathrm{h}^{-1}$ and dashed lines are isolines of $1 \mathrm{mb} \mathrm{h}^{-1}$. Arrows denote the time points when the wave troughs pass through the analyzed area.

sphere. However the phases of the response of deep and shallow clouds in relation to the wave structure differ considerably. Unimodal distributions are frequently observed with the dominance of deep or shallow clouds. The activity of deep clouds varies with a period of about 3-4 days corresponding to the variations of the large-scale wave disturbances. Mass fluxes due to shallow clouds exhibit time variations with a period shorter than that for the deep clouds. The relation between the convective activity and the African waves will be discussed in detail in the next section.

The time-height distribution of the convective downdraft mass flux is shown in Fig. 8. Strong downdrafts in the middle troposphere are generally found during periods with active deep clouds. In addition to the convective downdraft descending from middle layers to subcloud layers, there are downdraft mass fluxes limited to the lower troposphere probably from shallow clouds.

It has been well known from observational and theoretical studies of the interaction between large-scale motions and cumulus clouds that the

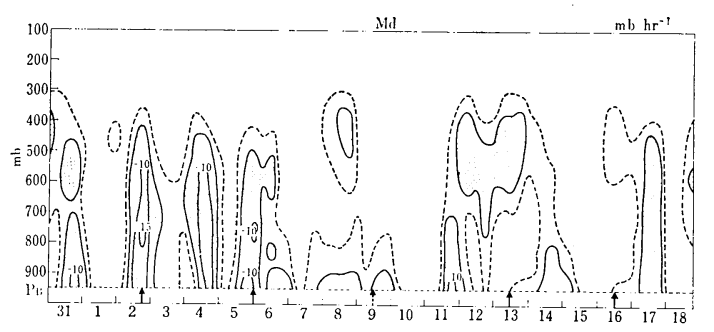

Fig. 8 As in Fig. 6 except for the cloud downdraft mass flux. Regions where downward flux is larger than $5 \mathrm{mb} \mathrm{h}^{-1}$ are shaded. Dashed lines are isolines of $-2.5 \mathrm{mb} \mathrm{h}^{-1}$. large-scale upward motion is an important parameter for determining cumulus development. To see the relation between the large-scale vertical velocity and the cloud mass flux, the correlation coefficients between these two variables are computed: Clouds are classified as deep, middle and shallow clouds according to their detrainment levels. Deep and shallow clouds are defined as clouds with tops above $400 \mathrm{mb}$ and below 700 $\mathrm{mb}$, respectively. Middle clouds have their tops between $700 \mathrm{mb}$ and $400 \mathrm{mb}$.

We compute the correlation coefficients between the cloud base mass flux for each cloud type and the large-scale vertical velocities at different levels with different time lags and obtain the maximum coefficients together with their time lags. Fig. 9 shows the maximum correlation coefficients for three cloud types. The deep cloud mass flux, $M_{B D}$, has large positive correlations with the large-scale vertical velocities, $\bar{M}$, at all levels. There is no time lag between $M_{B D}$ and $\bar{M}$ at higher levels above $600 \mathrm{mb}$, i.e., deep cumulus activity responds nearly instantaneously to the large-scale upward motion in the

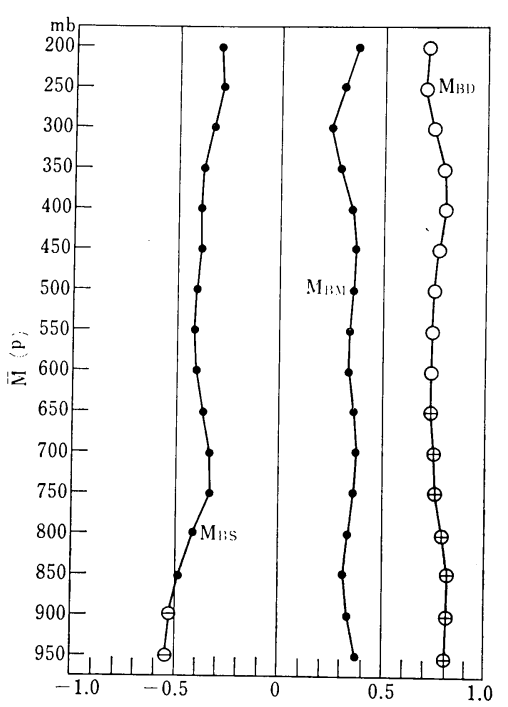

Fig. 9 Correlation coefficients between cloud base mass fluxes $M_{B}$ for deep, middle and shallow clouds, and the large-scale mass flux $\bar{M}(p)$ at all levels. Small and large circles denote correlation coefficients smaller and larger than 0.5, respectively. $\bigcirc, \oplus$ and $\ominus$ denote the results of maximum correlation coefficients obtained with zero, positive and negative time shifts of the cloud mass flux. 
upper troposphere. However maximum $\bar{M}$ at lower levels occurs earlier than maximum $M_{B D}$. Fig. 10 shows that maximum low-level convergence occurs about $6 \mathrm{~h}$ before the maximum deep cloud activity. This finding is consistent with results of correlation coefficients and time lags between the large-scale vertical velocities at different levels (not shown) indicating that maximum $\bar{M}$ in the lower troposphere occurs about $6 \mathrm{~h}$ before maximum $\bar{M}$ in the upper troposphere. The time lag between $M_{B D}$ and $\bar{M}_{950}$ would be response time of deep clouds to the low-level convergence but is longer than the life time for each isolated deep cloud which is only about $1 \mathrm{~h}$. $6 \mathrm{~h}$ time lag observed in this study could be understood as the response time for the development of an organized system of a deep cumulus convection. Strong areal-mean upward motion at higher levels observed about $6 \mathrm{~h}$ after the lowlevel convergence would be a result of the enhancement by the deep cumulus ensemble. The vertical shift of the maximum large-scale upward motion from the lower levels to the upper levels during an evolution of a cloud cluster has also been noted in $N$.

The results for deep clouds in this study partly agree with those by Ogura and Cho (1974),

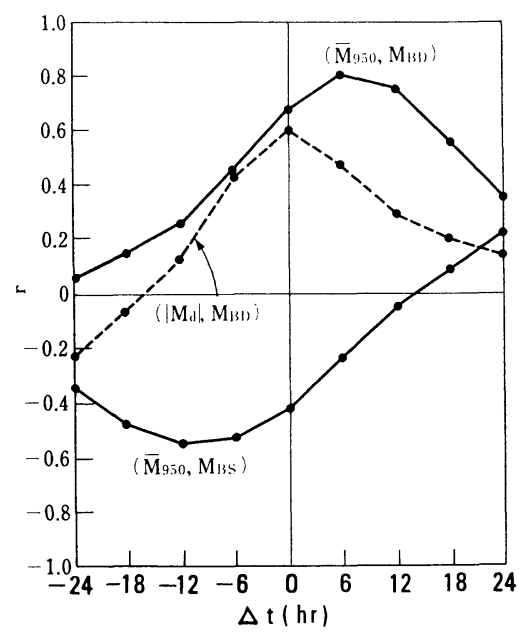

Fig. 10 Correlation coefficients between time series of the cloud base mass flux for deep and shallow clouds, and the large-scale mass flux at $950 \mathrm{mb}$ for different time shifts $(\Delta t)$ of the cloud base mass flux. Dashed lines are results between the deep cloud mass flux and the cloud downdraft mass flux at $525 \mathrm{mb}$.
Yanai et al. (1976) and Johnson (1978). Yanai et al. (1976) found that the cloud base mass fluxes for deep clouds are highly correlated with the large-scale vertical velocities at higher levels but could not find a significant correlation between deep clouds and the boundary-layer convergence. Ogura and Cho (1974) found a peak in deep cloud mass fluxes 15 hours after the maximum low-level convergence for the western Pacific wave composite of Reed and Recker (1971), and Johnson (1977) obtained a similar result for African wave disturbances at, and north, of the latitude of maximum wave amplitude. However they did not show the relation between the deep cloud mass flux and the largescale vertical velocity in the upper troposphere.

Middle cloud mass fluxes have small correlation coefficients with $\bar{M}$ (less than 0.5). The shallow cloud mass flux, $M_{B S}$, has negative correlations with $\bar{M}$ but the coefficients are small except near cloud base. The result of the correlation coefficients between $\bar{M}_{950}$ and $M_{B S}$ (Fig. 10) shows that the shallow cloud mass flux is generally small when the low-level convergence is large and that maximum $M_{B S}$ occurs about $12 \mathrm{~h}$ before the minimum low-level convergence. Johnson (1978) found similar relations in the region to the south of the wave reference latitude indicating that $M_{B S}$ is nearly $180^{\circ}$ out of phase with $M_{B D}$ and $\bar{M}_{950}$. He speculated that shallow cloud activity is suppressed as a result of downdraft stabilization of the subcloud layer. This would be true in the region to the rear of squall-line systems where mesoscale downdrafts dominate. However it is not likely that downdraft stabilization affects the whole large-scale area as the GATE A/B-scale. It is more probable from the point of large-scale control on cumulus development that most cumulus clouds are forced to develop into deep clouds by the strong low-level convergence and only few clouds loose their buoyancy in the lower troposphere. Further observational and theoretical studies are required to clarify large-scale controls on shallow clouds. The results of the correlation coefficients between $M_{B D}$ and the downdraft mass flux at 525 $\mathrm{mb}$ (Fig. 10) confirms the previous conclusion that the strong downdraft mass flux is associated with the active deep clouds.

\section{Cumulus clouds associated with the African wave disturbance}

As mentioned in the previous section, the large- 


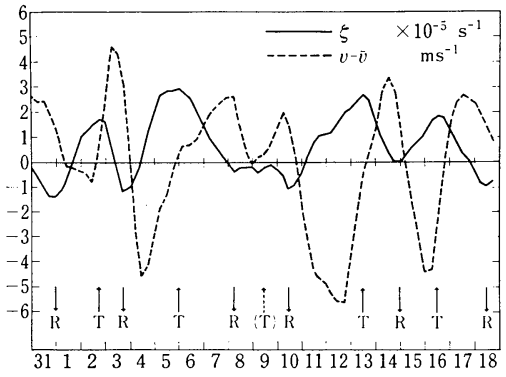

Fig. 11 The relative vorticity and the north-south wind deviation from the time mean at $700 \mathrm{mb} . T$ and $R$ denote trough and ridge of the wave disturbance, respectively.

scale motion systems vary with a 3-4 day period corresponding to the passage of the wave disturbances and cumulus activity changes accordingly. The African wave disturbance propagates westward with a mean period of 3.5 days and a mean wavelength of about $2,500 \mathrm{~km}$. Time variations of the north-south wind component and the relative vorticity at $700 \mathrm{mb}$ where the wave amplitude is largest are plotted in Fig. 11. Both parameters oscillate regularly with periods of 3 to 4 days except around 9 September, 1974. Synoptic weather maps (not shown) show that the disturbance center is located far from the GATE area on 9 September, 1974. Variations of the relative vorticity and the deviation of the $v$-component from the mean correlate well with each other. The time of the maximum relative vorticity nearly coincides with the time at which $v-\bar{v}$ changes from northerly to southerly winds, and the reverse phase relation holds for the minimum relative vorticity.

A compositing method is used to obtain relationships between the wave disturbance and the cumulus convection. Four waves observed over the GATE A/B-area during Phase III are used for the wave compositing. The 9 September wave was not used. Maximum and minimum relative vorticities at $700 \mathrm{mb}$ are used to define the wave trough and ridge, respectively. The intermediate period between each trough and ridge is linearly divided by four wave categories to give eight categories per wavelength.

Figs. 12-14 show the vertical distributions of the relative vorticity, the horizontal divergence and the vertical $p$-velocity for the composite wave. The cyclonic vorticity is found near the wave trough with a peak at $700 \mathrm{mb}$ and the

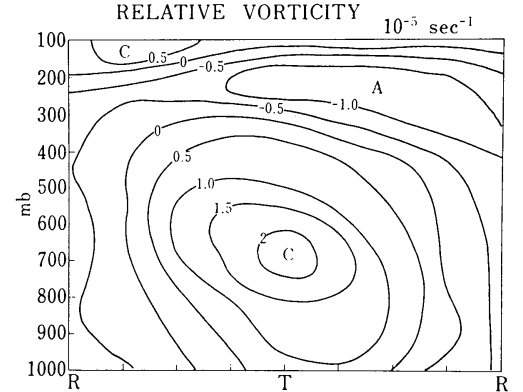

Fig. 12 Vertical cross section of the relative vorticity for the composite wave. $T$ and $R$ denote wave trough and ridge, respectively. The phase on the left of the abscissa leads to that on the right.

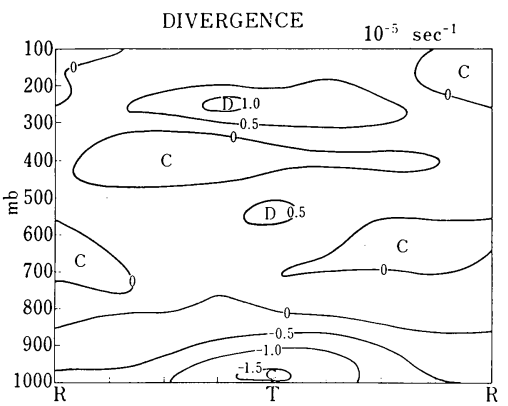

Fig. 13 As in Fig. 12 except for the horizontal divergence.

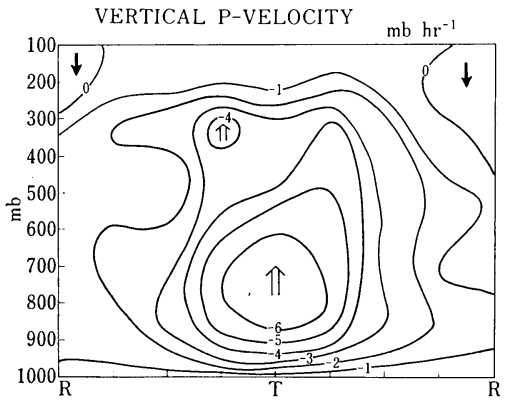

Fig. 14 As in Fig. 12 except for the vertical $p$-velocity.

anticyclonic vorticity is found in the upper troposphere around $200 \mathrm{mb}$. Strong convergence exists below $800 \mathrm{mb}$ with a peak near the trough and divergence around $200 \mathrm{mb}$, with a peak slightly ahead of the trough. Weak divergence and convergence are found in the middle troposphere. The upward motion dominates the whole troposphere at almost all wave phases, and its 
maximum is located near the trough region. The composite structures of the wave disturbance obtained in this study are consistent with the results obtained by Reed et al. (1977). They found strongest upward motion in advance of the wave trough at the wave reference latitude which is about $4^{\circ}$ north to the center of the GATE A/B-area. However, their analysis of the horizontal distributions of the relative vorticity and the vertical velocity shows that the maximum upward motion occurs nearly at the wave trough in the southern region of the wave reference latitude which roughly corresponds to the analyzed area in this study.

Fig. 15 shows the distribution of $M_{B}\left(p_{D}\right)$. Strong mass fluxes accompanied by deep clouds occur near the wave trough where the vertical velocity is the largest, but shallow cloud activity is very weak there and the largest shallow cloud mass fluxes are found near the wave ridge. These results are consistent with those in the previous section. Reed et al. (1977) and Payne and McGarry (1977) examined relationships of convective activity to African wave disturbances using SMS-1 infrared brightness and found that the maximum deep convective activity occurs in the region where the vertical velocity is the largest. However modulations of shallow clouds by the wave have not been analyzed.

The distribution of the downdraft mass flux is presented in Fig. 16. Strong convective downdrafts are found in the vicinity of the trough region where deep clouds are most active. There also exist strong cumulus downdrafts near cloud base in the regions apart from the wave trough which may be caused by shallow clouds.

Mass fluxes in the environment of the clouds are shown in Fig. 17. Weak subsidence with values of a few $\mathrm{mb} \mathrm{h}^{-1}$ generally exists in the

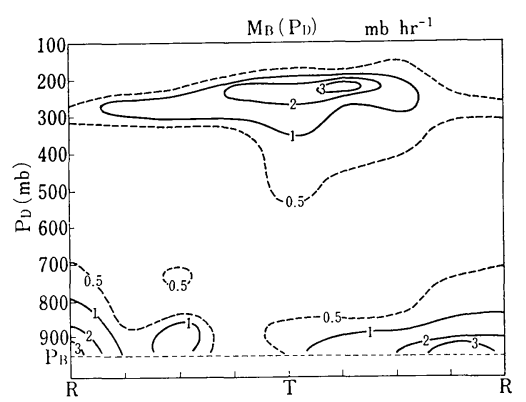

Fig. 15 As in Fig. 12 except for the cloud base mass flux as a function of the detrainment level.

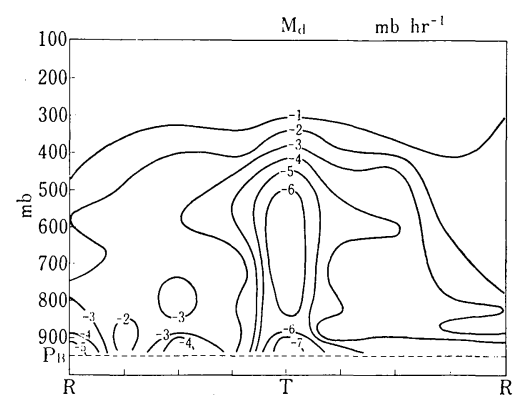

Fig. 16 As in Fig. 12 except for the cloud downdraft mass flux.

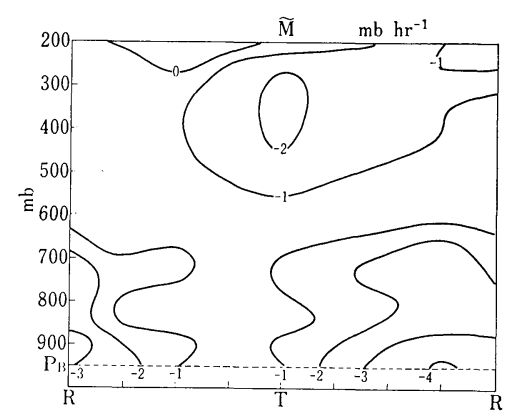

Fig. 17 As in Fig. 12 except for the environmental mass flux between clouds.

whole layer, but considerable subsidence occurs near cloud base in the vicinity of the ridge where shallow clouds are very active. The environment of the clouds near cloud base is cooled and moistened by the detrainment from shallow clouds and these cooling and moistening effects are balanced by the warming and drying effects by the environmental subsidence. Therefore if shallow clouds are active, the subsidence between clouds would be strong there. Moderate environmental subsidence is also found in the upper troposphere near the trough where deep clouds are active. Warming by the subsidence in this layer may be balanced by the cooling due to detrainment from deep clouds.

The results of the cumulus response to the African wave over the GATE A/B-area generally agree with those in the region to the south of the wave reference latitude obtained by Johnson (1978). Some of the small differences between his study and the results reported here may be partly due to the difference of the methods determining cumulus mass fluxes and the differences in the data used for this analysis. Some differences may also be expected from the fact that 
Johnson's composite wave includes waves over both land and ocean.

\section{Summary and concluding remarks}

The response of cumulus updrafts and downdrafts to large scale forcing is examined by using upper-air observations over the GATE A/B-scale area during Phase III. The diagnostic method developed by $N$ is used to determine properties of cumulus updrafts and downdrafts. The timeaverage profiles of the area-averaged relative vorticity, horizontal convergence and vertical velocity over the GATE area are similar to those commonly observed in the other ITCZ regions such as the western Pacific and the western Atlantic to some extent, but there are several differences as already noted by Reed et al. (1977) and $N$. In the time averages, deep and shallow cloud mass fluxes are much larger than the vertical mass transports of middle clouds, and strong cumulus downdrafts with the amplitude of $40 \% \sim 50 \%$ of updraft mass fluxes are found in the middle and lower troposphere. The total vertical mass transports in the clouds are slightly larger than those averaged over the analyzed area and thus the weak subsidence is found in the environment of the clouds.

Large-scale parameters and cumulus activity over the GATE area vary in time corresponding to the fluctuations of the synoptic weather situations. Correlation coefficients and time lags between deep, middle and shallow cloud mass fluxes and large-scale vertical velocities at all levels, are computed to examine the response of cumulus clouds to the large-scale forcing. Mass fluxes for deep clouds have strong positive correlations with the large-scale vertical velocity at all levels. The maximum cloud mass flux for deep clouds occurs nearly at the same time as the maximum large-scale vertical velocity in the upper troposphere but about $6 \mathrm{~h}$ after the maximum low-level convergence. Shallow cloud activity has a negative correlation with the vertical velocity near cloud base indicating that shallow cloud activity is weak when the low-level convergence is large and strong when the convergence is small. Middle clouds have little correlations with the large-scale vertical velocity.

The GATE A/B-scale area is affected by the African wave disturbance travelling with a period of about 3.5 days, and cumulus activity is highly associated with the wave. Four waves during Phase III are used for wave compositing to obtain the relation between the wave and the cumulus convection. Maximum deep cloud mass fluxes occur in the vicinity of the trough where the strongest large-scale upward motion is found. Strong cumulus downdrafts are also found around the trough. On the other hand shallow cloud mass fluxes are very small near the wave trough, but large near the wave ridge. In general, the structure of the wave composite and associated cumulus activity obtained in this study agree with those analyzed in the region to the south of the wave reference latitude by Reed et al. (1977) and Johnson (1978).

The results of the cumulus response to the large-scale forcing obtained in this study depend upon the diagnostic cloud model used for analysis. Johnson (1976) and $N$ showed that results for deep cloud mass fluxes are not altered by the neglect of cumulus downdrafts, but shallow cloud mass fluxes are overestimated. Cho and Ogura (1974) and Yanai et al. (1976) found no clear relationships between shallow cloud activity and the large-scale motions using a model without downdrafts. Observational verification of cumulus activity is needed to judge the results obtained by the diagnostic cloud models. Preliminary comparisons between cumulus activity obtained by the diagnostic method and direct observations of cumulus clouds are now being investigated.

Although manners of response of cumulus updrafts and downdrafts to the large-scale forcing obtained in this study are suggestive, this type of analysis gives us only the instantaneous balance between large-scale motions and cumulus clouds. It is not easy to conclusively determine cause and effect from these diagnostic results. Theoretical and numerical studies are needed in future to clarify exact situations under which cumulus ensembles respond to varying large-scale fields.

\section{Acknowledgements}

The author wishes to express his thanks to Professor M. Yanai for his helpful support during the initial course of this work. He also thanks Dr. S. Esbensen for reviewing and making valuable comments on the manuscript, and Dr. M. Yamasaki for his useful comments. Thanks are also due to Mrs. K. Kudo for typing the manuscript. This work was supported by Scientific Research Funds from the Ministry of Education.

\section{References}

Arakawa, A., and W. H. Schubert, 1974: Interaction 
of a cumulus cloud ensemble with the largescale environment, Part I. J. Atmos. Sci., 31, 674-701.

Betts, A. K., 1973: Non-precipitating cumulus convection and its parameterization. Quart. J. Roy. Meteor. Soc., 99, 178-196.

Cho, H.-R., and Y. Ogura, 1974: A relationship between cloud activity and low-level convergence as observed in Reed-Recker's composite easterly waves. J. Atmos. Sci., 31, 2058-2065.

Dopplick, T. G., 1970: Global radiative heating of the earth's atmosphere. Rep. No. 24, Planet, Circ. Project, Dept. of Meteorology, MIT, $128 \mathrm{pp}$. (Nuclear Science Abstracts, Cumulative Report Number Index MIT-2241-58.)

Frank, W. M.; 1977: Convective fluxes in tropical cyclones. J. Atmos. Sci., 34, 1554-1568.

Houze, R. A., 1977: Structure and dynamics of a tropical squall-line system. Mon. Wea. Rev., 105, 1540-1567.

Johnson, R. H., 1976: The role of convective-scale precipitation downdrafts in cumulus and synopticscale interactions. J. Atmos. Sci., 33, 1890-1910. , 1978: Cumulus transports in a tropical wave composite for Phase III of GATE. J. Atmos. Sci., 35, 484-494.

Nitta, T., 1975: Observational determination of cloud mass flux distributions. J. Atmos. Sci., 32, 73-91.

, 1977: Response of cumulus updraft and downdraft to GATE A/B-scale motion systems. J. Atmos. Sci., 34, 1163-1186.

Ogura, Y., and H.-R. Cho, 1973: Diagnostic deter- mination of cumulus cloud populations from observed large-scale variables. J. Atmos. Sci., 30, 1276-1286.

Ooyama, K., 1971: A theory on parameterization of cumulus convection. J. Meteor. Soc. Japan, 49 (Special Issue), 744-756.

- and S. Esbensen, 1977: Rawinsonde data quality. Report of the U.S. GATE Central Program Workshop, NSF, NOAA, 131-164.

Payne, S. W., and M. M. McGarry, 1977: The relationship of satellite inferred convective activity to easterly waves over west Africa and the adjacent ocean during Phase III of GATE. Mon. Wea. Rev., 105, 413-420.

Reed, R. J., and E. E. Recker, 1971: Structure and properties of synoptic scale wave disturbances in the equatorial western Pacific. J. Atmos. Sci., 28, 1117-1133.

D. C. Norquist and E. E. Recker, 1977: The structure and properties of African wave disturbances as observed during Phase III of GATE. Mon. Wea. Rev., 105, 317-333.

Yanai, M., S. Esbensen and J.-H. Chu, 1973: Determination of bulk properties of tropical cloud clusters from large-scale heat and moisture budgets. J. Atmos. Sci., 30, 611-627.

- J.-H. Chu, T. E. Stark and T. Nitta, 1976: Response of deep and shallow tropical maritime cumuli to large-scale processes. J. Atmos. Sci., 33, 976-991.

Zipser, E. J., 1977: Mesoscale and convective-scale downdrafts as distinct components of squall-line structure. Mon. Wea. Rev., 105, 1568-1589. 


\title{
GATE 領域における積雲対流と大規模運動との相互作用
}

\author{
新田就 \\ 東京大学理学部地球物理学教室
}

積雲対流と大規模運動との相互作用を明らかにするために, GATE の Phase III のデータに, 積雲による上昇 流, 下降流を取り入れた解析モデルを適用した。解析期間の平均では, 背の高い雲と低い雲による mass ffux が卓 越し，中層に雲頂を持つ雲による寄与は小さい。積雲内上昇流の 40 ～ $50 \%$ に相当する量の積雲内下降流が存在する。

積雲を背の高い雲, 中位の雲, 背の低い雲の三種類に大別し, それらの mass ffux と各レベルでの大規模平均上 昇流との相関係数を計算した。背の高い積雲による mass ffux の変動は全層での平均上昇流の変動と高い相関関係 を示す。一方中位の積雲と平均上昇流との間には相関はなく，また背の低い積雲は，雲底付近の平均上昇流との間に 相関を有する。背の高い雲による mass ffux は, 上部対流圈の大規模上昇流が最大となる時に最も大きな值を示す が，これはまた下層の上昇流の最大が現われてから約 6 時間後に相当している。積雲内下降流が強く現われるのは背 の高い雲の活発な時に対応している。背の低い雲の mass ffux は, 下層の大規模水平収束の変動と負の相関を有し, 水平収束の強い時期に低い雲は不活発となっている。

GATE 期間中，アフリカ大陸内部から東部大西洋域へ，波動擾乱が伝播することが知られているが，この波動と 積雲対流との関係を調べるために波動に関する合成図を作成した。波動のトラフ付近で大規模上昇流の最大があり， 背の高い雲の活動が最も盛んである。ここではまた積雲内下降流が最も強く存在している。一方背の低い雲は, 波動 のトラフ付近では不活発で, リッジ付近で逆に活発となっている。雲と雲の間には, 数 $\mathrm{mb} \mathrm{h}^{-1}$ の弱い下降流が存在 し，この下降流は，背の低い雲の活発な所で他よりやや強くなっている。 